\title{
Orientalism's Suspicions about the Prophet's Infallibility andResponding against them "The Orientalist Schacht as a model"
}

\author{
Fatma Ibrahim Ali Radwan ${ }^{\text {a }}$ Farida Mohammed Alli Aqilib \\ aAssistant Professor, Prince Sattam Bin Abdulaziz University, Saudi Arabia, fatmarad980@gmail.com \\ ${ }^{\mathrm{b}}$ Assistant Professor, Prince Sattam Bin Abdulaziz University, Saudi Arabia, f.aqaili@ psau.edu.sa
}

Article History: Received: 10 November 2020; Revised 12 January 2021 Accepted: 27 January 2021; Published online: 5 April 2021

\begin{abstract}
This study aims at elucidating and clarifying Islam's position towards orientalists' opinions concerning the infallibility of the Prophet Mohammad Peace and Prayers by Upon Him (PPUH) in his acts and diligence (ijtihad) through investigating the orientalist literature and resources in which the suspicions occurred are related to the research subject. Then analyze and criticize those suspicions by referring to Islamic authenticity sources. The research concluded that the claims of orientalism collapsed in the face of the absence of logical and written evidences concerning the subject of infallibility. The research also recommended the importance of paying attention to orientalist studies and intensifying the efforts to overcome these suspicions with thought, study and research.
\end{abstract}

Keywords: Orientalism, Prophet's Infallibility, The Orientalist Schacht

\section{Introduction}

Praise be to our Almighty God, from whom we praise, seek assistance and forgiveness. We seek refuge from Almighty God from the sins of ourselves and from our bad deeds. Whom Almighty God guides, will not to be misguided, and whom Almighty God misguided, will not to be guided, and I do witness that there is no god but Almighty God alone without a partner, and I do witness that Mohammad PPUH is his servant and messenger.

The Islamic Ummah has been ravaged by many seditions and campaigns that try to undermine the religious principles of Muslims. Among which is what the orientalists raised about the infallibility of the Prophet (PPUH) in his acts and diligence (ijtihad) and about the independence of his Sunnah for their relationship with the most important source of legislation, which is the Prophet's Sunnah, which is indispensable in the statement and legislation of the provisions. Therefore, we find the (orientalists) enemies' endeavors and keenness to undermine and overcome Islam and those who belong to Islam in the past and present as well as suspecting Islam's authenticity to make lose the most important source of its power and to facilitate destabilizing the Muslims from their values.

Therefore, we wanted to have a role in repelling and defending our true in faith religion and to eliminate these suspicions aimed at suspecting the Islamic values. We hope that Allah will grant us success, repayment and reward.

The research answers the following main question: What are the orientalist Joseph Schacht's opinions towards the prophet's infallibility? This question is branched out by the following sub-questions:

i. What evidence on which Schacht's claim was based that the Prophet PPUH was not infallible of his actions and diligence (ijtihad)?

ii. What does Joseph Schacht think of the independence of the Sunnah of the Prophet (PBUH) in the legislation?

iii. How can Joseph Schacht's allegations be discussed and analyzed in the light of logical and written evidences?

\section{Research importance and the selection reasons}

i. Correcting the misleading suspicions about the prophet's infallibility in his acts and diligence (ijtihad).

ii. Drawing the researchers' attention to the destruction shovels in the Islamic Ummah who do not believe in the prophet's infallibility, aiming at suspecting the authenticity of the Prophet's Sunnah.

iii. Opening the door for researchers to criticize the suspicions of the orientalists and others who belong to Islam, who seek to undermine Muslim ideas, and to question their religious values. 
iv. Enriching the Islamic libraries with such researches, which has a major role in addressing whatever may compromise the sources of Islamic Sharia.

\section{Search objectives}

i. Proving the Prophet's infallibility in his acts and diligence (ijtihad), through the scientific authenticity literature in the field of diligence (ijtihad).

ii. Illustrating the prophet's infallibility and to show that it is a religious necessity, for Al-Sunnah authenticity interdepend on it.

\section{Literature Review}

Some of the most important studies, which dealt with suspicions about the Prophet's infallibility and the independence of his Sunnah include:

i. The opinions of the orientalist Joseph Schacht on the authenticity of the Prophet's Sunnah through his book The Origins of Mohammadia Sharia. Master's Thesis. By: Mohamed Ibrahim Noor Abdultif Khalifa.

ii. Responding against the suspicions of the Prophet's infallibility in the light of the Holy Quran and the Sunnah, by: Dr. Emad Al-Sayyid Al-Sharbini.

iii. The independence of the Sunnah by the legislation of provisions. By: Alaa Ibrahim Abdul Rahim. Researcher at the Salaf Center for Research and Studies.

iv. Orientalist projection in Sunnah suspicions. By: Ammar Mohammed Akbar. Salaf Center for Research and Studies.

The previous studies did not address the subject of infallibility independently, but briefly have referred to it, which led to the emergence of some aspects that have not been fully addressed, which the current study has addressed. This study came to identify these suspicions in more research and details, and to complement what the previous studies have briefly addressed.

\section{Research Methodology}

The research uses the descriptive approach, by addressing the orientalists' ideas and suspicions while using the analytical approach of those suspicions. The inference approach is followed by the research to respond to the orientalists' claims through the inference of authenticity in Islamic literature.

\section{Research Plan}

The study contains an introduction, two components and a conclusion The first component: the concept of the prophet's infallibility. The second component: the suspicions about the of the Prophet's (PPUH) infallibility in his acts and diligence (ijtihad), and the response to them.

The first component: the concept of the prophet's infallibility. From the suspicions and false allegations that revolved around suspecting the Prophet's Sunnah, is the Prophet's (PPUH) infallibility in his acts and diligence (ijtihad). To illustrate this suspicion, and how to respond to it, it is necessary to understand the concept of infallibility.

First: infallibility in language: infallibility has several definitions; the most important of which, Prevention it is said: I prevented him from lying. That is, he stopped and prevented him from doing so. It also has meaning preservation. It is said that Almighty God preserved him from hatred incidents. That is, saved and protected him (Ibn Mandhoor, D.T, 12/402).

Second: the infallibility in idiomatic: the definitions of scholars in the definition of infallibility, such as:

i. $\quad$ "It distracts the causes of sin from committing sins, so Almighty God inspire the infallible to be desired and intimidated." (Al-Fatuhi, 2003, 2/167)

ii. It was said: "It is the preparation of the slave for his inclusive approval, and this is due to the creation of the ability to obey. Therefore, the infallibility is an inclusive success." (Mardawi, 2000, 3/1437).

Perhaps the best thing that has been said in the definition of the prophet's infallibility is the definition of Ibn Hajar, when he defined it by saying: "preserved them from the inadequacies and allocating them to psychological perfections, victory, stability in things, and granting them tranquility". He also said; "The difference between them and others is that the infallibility on their way is obligatory, and for others is permissible" Al-Askalani, D.T., 11/229".

The second component: the suspicions about the of the Prophet's (PPUH) infallibility in his acts and diligence (ijtihad), and the response to them. 
There have been several false suspicions raised by orientalists about the Prophet's infallibility, and we can limit all of these suspicions and respond to them, as follows:

\subsection{The first suspicion:}

There is not any evidence in the Holy Qur'an that the Sunnah is infallible, nor is there the Prophet's (PPUH) infallibility from making mistakes. The Orientalist Schacht said about this: "And if the greater part of the diligence (ijtihad) is based on the Sunnah of Mohammad the right ones and the false ones" the Muslims considered the Sunnah to be a departure from making mistakes; it is difficult to find this opinion in the Qur'an" (The Al-Calipha, 1997, p. 131).

To respond to this suspicion; This claim is nothing but a false claim based on hiding the truth and his infallibility, because the evidences from the Holy Quran to prove his infallibility are quite a lot, which can't be mentioned all of them here. However, I will merely mention some of these evidences, and their statement is as follows:

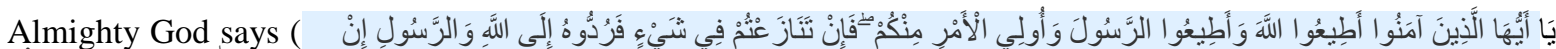

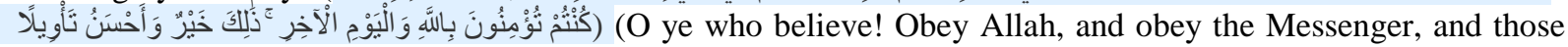
charged with authority among you. If ye differ in anything among yourselves, refer it to Allah and His Messenger, if ye do believe in Allah and the Last Day: That is best, and most suitable for final determiUmmah ) Surrah AnNisa: Verse 59.

The indication of this Holy Verse: This Holy Verse indicated two things:

First: Almighty God commands his servants to obey him and obey his Messenger (PPUH). In addition, his obedience is achieved by complying with all the revelations he has revealed to his Messenger (PPUH). The obedience to his Messenger is fulfilled by complying and following all the judgments that his Messenger (PPUH) informs us whether it comes from revelation or his diligence (ijtihad) (PPUH). Otherwise, the mentioning of obedience to the Prophet (PPUH) after mentioning the obedience to Almighty God would not have been useful. Thus, it is clear that the allocation of mentioning the obedience to the Prophet in the Holy Verse is a proof of his infallibility in his acts and diligence." (Almowafikat 3/-229).

Second: Almighty God commanded in this verse to return the disputants in any order to return to Allah and to his Messenger (PPUH), and to return to Almighty God by referring to the revelation he revealed to his Messenger (PPUH). Whether it is cited from the Holy Quran or not cited like Prophetic Sunnah. With a regard to the return to his Prophet (PPUH) it is necessary to refer to the Prophet's diligence (ijtihad) (PPUH), and we must obey in that regard. It is not involved in the revelation; otherwise it will have to be repeated." (Sharbini, 2003, p. 415-416).

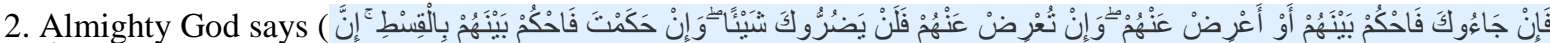

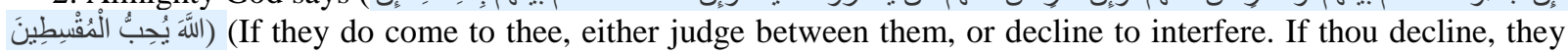
cannot hurt thee in the least. If thou judge, judge in equity between them. For Allah loveth those who judge in equity) Surrah Al-Maeda: Verse 42.

The indication of this Holy Verse, This Holy Verse indicated two things:

First: Almighty God has delegated the judging among them to his Prophet and makes him choose between judging among them with his diligence (ijtihad) if he finds an interest, or to ignore them if there is no harm to him.

Second: Almighty God has commanded his Prophet (PPUH) to judge among them. His judgment shall be restricted by justice. This is considered as an alert for the Prophet (PPUH) to investigate the truth and the right when judging among them. This is proof of Almighty God's permission to his Prophet to judge among them with his diligence. If the intention is to judge by the revelation, this restriction would not be beneficial for the Prophet because he only judges with justice. This indicated his infallibility of his diligence (ijtihad) in what he (PPUH) judges. (Sharbini, 2003, p. 416)

\subsection{Second suspicion:}

Muslims do not consider the prophet's infallibility in his acts, but his human acts are prone to errors. Orientalist Schacht said; "From the very beginning, the Prophet's authenticity in Islam was not suspected. Even in the things, which were not involved in Holy Quran. However, at the same time, his acts were considered purely human acts, even those that are related to the religion. So his acts were not considered infallible, and I criticized these acts more than once. The Holy Quran itself sometimes blamed him for some of his acts." (Al-Calipha, 1997, p. 131).

To respond to this suspicion;

The consensus of the Ummah on the Prophet's infallibility in his acts and legislative diligence (ijtihad) because he has (PPUH) does not admit to wrong; (Jouini, 1996, 2/226). Imam Al-Shatabi stated that the Prophet (PPUH) is 
infallible in his diligence (ijtihad) with no dispute among the scholars, as he said: "you should know that the Prophet is a supported by diligence (ijtihad) and is supported by the miracle, which is an indication to the truth of and soundness of what he said". Moreover, you notice his diligence (ijtihad) is infallible, with no dispute. Either he does not make mistakes or he does not accept any wrong dead if imposed. Then what is your idea about other things?" (Al-Shatabi, 1997, 4/83). He also said " The hadith is either inspired by God, or by the diligence (ijtihad) of the Prophet (PPUH) and is considered to be a true inspiration from Holy Quran or Al-Sunnah, and on both

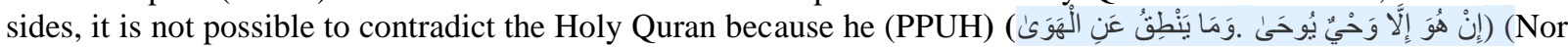
does he say (aught) of (his own) Desire. It is no less than inspiration sent down to him) Surrah An-Najm: Verse $3 \& 4)$. Moreover, if he is done saying that, it is permissible for him to go wrong; he will not admit it at all. We have to go back to the right thing. The brunching of the saying that should not be judged by his diligence, which is contrary to the Holy Quran" (Al-Shatabi, 1997, 4/21).

Imam Al-Subki said concerning his diligence (ijtihad) (PPUH): "the right is to say that his diligence (ijtihad) (PPUH) does not make mistakes." (Attar, 1999, 2/426). Al-Khattabi said, "We are unanimous that his acceptance of making mistakes is not permissible".

It is known to Muslim scholars that the infallibility of the Prophet (PBUH) in his words, actions. In addition, all that he says and acts without inspiration is from Islam because the revelation watches him and won't let anything contrary pass. This is witnessed by the statement sought by Jaber bin Abdullah, who said: " we used to practice coitus interrupt us while the Qur'an was being revealed". Sofian said: one of the trustworthy men in the hadith narration, Explains the words of Jaber bin Abdullah " If there is anything to forbid us, we would have been forbidden by the Holy Qur'an." (Transmitted by A Muslim in Sahih, The Book of Marriage, Chapter: The coitus interrupts (2/1065), no. (1440). Dr. Abdul Mahdi Abdul Qadir commented on this effect: It appears to me from Jaber's words that Jabera inferred the legitimacy of coitus interruptus by the acceptance of Almighty Allah. Accordingly, Jaber believes that the revelation is not restricted to watching the Prophet, but also the whole Ummah. Whoever acted in contrary to Islam, the revelation will expose him. Moreover, whatever they acted at the time of revelation, and the revelation acknowledged it, it is from Islam." (Abdelkader, 2007, 72).

There is a contradiction in what Schacht said about this suspicion, and this is reflected in his words: " From the very beginning, the prophet's authenticity in Islam was not suspected" which contradicted his statement "With this, it was not considered infallible". The first decided that the Sunnah among Muslims is authenticity that is not in suspected even in the rules that are not involved in the Holy Qur'an. The second, the acts of the Prophet (PBUH) are not considered infallible", and this is a clear contradiction because the prophet's authenticity it is meant to be sayings or actual authenticity. In addition, the authenticity requires that it should not be violated because they are meant to be right that do not lead to make a mistake.

\subsection{Third suspicion:}

The acts of the Prophet (PBUH) have sometimes been criticized in the Holy Qur'an. Besides, Muslims have criticized them in more than one position. This is what Schacht claimed: " These acts were criticized more than once; the Holy Quran itself sometimes blamed him for some of his acts (Al-Caliph, 1997, p. 131).

To respond to this suspicion;

i. Their false claim that his acts have been criticized more than once, we say: What is your proof for this, it has not been proven that one of the Sahaba, followers or Muslim scholars did so. It is agreed by all Muslim scholars that, "Those who are actually suffering from the acts of the Prophet (PPUH) are considered infidel or disbelievers." (Shahrastani, 1404H, 3/142).

ii. Their claim that the Holy Qur'an criticized him was based on what they had inferred from some of the Holy Verses, which appeared to reproach or blame the Prophet, such as Almighty God saying:

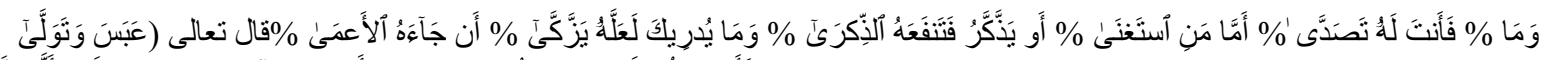

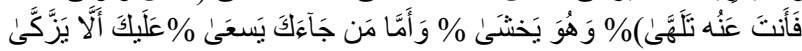

Almighty God says ( The Prophet) frowned and turned away, Because there came to him the blind man (interrupting), But what could tell thee but that perchance he might grow (in spiritual understanding)?, Or that he might receive admonition, and the teaching might profit him?, As to one who regards Himself as self-sufficient, To him dost thou attend;Though it is no blame to thee if he grow not (in spiritual understanding), But as to him who came to thee striving earnestly, And with fear (in his heart), Of him wast thou unmindful) Surrah Abasa: Verses 1- 10 .

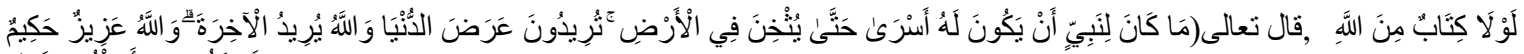

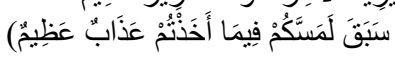


Almighty God says ( It is not fitting for a prophet that he should have prisoners of war until he hath thoroughly subdued the land. Ye look for the temporal goods of this world; but Allah looketh to the Hereafter: And Allah is Exalted in might, Wise, Had it not been for a previous ordainment from Allah, a severe penalty would have reached you for the (ransom) that ye took. Al-Anfal: Verses 67- 68.

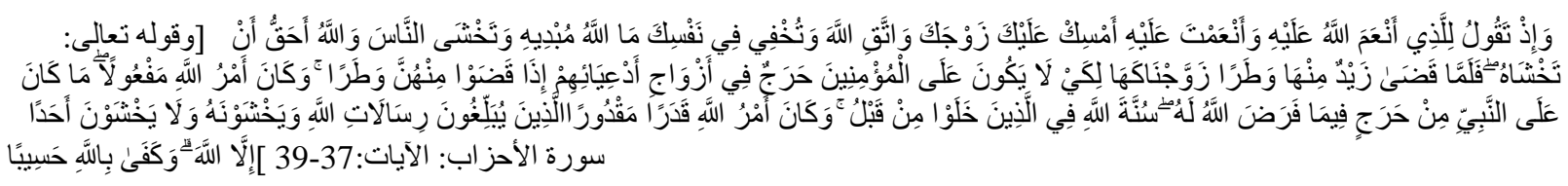

Almighty God says (Behold! Thou didst say to one who had received the grace of Allah and thy favour: "Retain thou (in wedlock) thy wife, and fear Allah." But thou didst hide in thy heart that which Allah was about to make manifest: thou didst fear the people, but it is more fitting that thou shouldst fear Allah. Then when Zaid had dissolved (his marriage) with her, with the necessary (formality), We joined her in marriage to thee: in order that (in future) there may be no difficulty to the Believers in (the matter of) marriage with the wives of their adopted sons, when the latter have dissolved with the necessary (formality) (their marriage) with them. And Allah's command must be fulfilled. There can be no difficulty to the Prophet in what Allah has indicated to him as a duty. It was the practice (approved) of Allah amongst those of old that have passed away. And the command of Allah is a decree determined. (It is the practice of those) who preach the Messages of Allah, and fear Him, and fear none but Allah. And enough is Allah to call (men) to account.

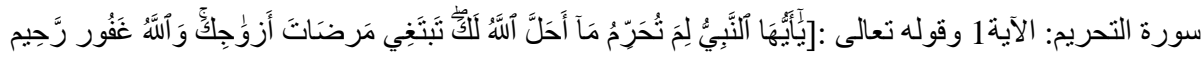

Almighty God says (O Prophet! Why holdest thou to be forbidden that which Allah has made lawful to thee? Thou seekest to please thy consorts. But Allah is Oft-Forgiving, Most Merciful.

$$
\text { وقوله تعالى: عَفَا الْلَّهُ عَنَكَ لِِحَ أَذِنتَ لَهُم] سورة التوبة: الآية 43: }
$$

Almighty God says (Allah give thee grace! Why didst thou grant them until those who told the truth were seen by thee in a clear light, and thou hadst proved the liars?

Muslim scholars have stood by these verses and explained the possibilities, which these verses should be carried, and they responded to the suspicions that have been going on around her in details. However, I will limit myself to mentioning the response to these suspicions in general, and to say this as follows: (Al-Hasabi, 1984, 2/141).

The Qur'anic verses, in which the prophets are reproached, look like a reproach in their manifestation, but in fact, they are a reward (karamah) and closeness to Almighty God. In addition, it is a kind of alert to others who are not in their class of human beings. By holding them accountable when they do so, they are committed to thanks for the graces, the patience for adversities, and the repentance at the slip. It is that Almighty God reproaches his chosen prophets and discipline them, and hold them accountable for the major or minor deeds without being suspected in their perfection. The prophets' words and deeds in which the reproach was signed by Almighty God was about a permissible act. The prophets can act the permissible acts, and there is no underestimation of their position nor their infallibility. They do not act from the permissible except when there is a necessity that they are strengthening on the righteousness of their religion and their world. Therefore, what has been taken in this way has been obedience and closeness.

It does not necessitate that whoever does it shall to be blamed because the blame could be blackguard, or it could be a reproach. If this the blame occurred, It was from a reproach from Almighty God not a blackguard because those who are reproached, enjoys the state of being pleasant. (See: Al-Jazari, 1979, 1/327).

There is not any blaming for the prophets occurred, peace and prayers by upon them, if so, they would be reproached and then blackguard.

What they claim to be criticism is a reproach and an alert to him for his best choice with the existence of the best. Because the prophets are diligent imams in the things, which there is no revelation about them. Sometimes, their diligence (ijtihad) may not reach perfection, so divine guidance comes with alerting and guidance for the best and the most comprehensive. They should not have to be reproached for making a mistake not suspecting their infallibility. Rather, divine guidance directs them to the best, and their insistence on not to make mistakes is a sign of their infallibility. Moreover, the contemplator in the verses of reproach, in which Almighty Allah reproached the Prophet (PPUH) or reproach his prophets' peace and prayers be upon them, finds that it included a wisdoms and secrets to Almighty Allah in leaving his messengers peace and prayers be upon them make diligence. Then he reproaches them and directs them if they violate the first or make a mistake, including the following: (Al-Sharbini, 2003, p. 412-413.). 
Establishing the proof of the prophet's humanity and his slavery to Almighty God, and that being the messenger and the Almighty God best created human, he did not go beyond being a slave of Almighty God who makes mistakes and does right, as humans make mistakes and do right, but he does not insist on making the mistake.

It is an evidence and a proof of the Prophet's (PPUH) infallibility and his honesty in transporting the message and not hiding anything from what the Almighty God descends, if he disguises anything out, he will disguise the verses of reproach.

Encouraging the Ummah for diligence (ijtihad), the Prophet's diligence (ijtihad) arisen when there was no revelation clarifying worldly issues, is encouraging the Muslim scholars to execute diligence (ijtihad) when presenting them with the issues and events about which they do not find clear Quranic texts.

Emphasizing the importance of working in Shura, this is supported by what was transmitted by Ibn Abbas " when the verse [وَشَاوِ هُم فِي ألأَمرِ] (and consult them in affairs (of moment) Surrah Aal-e-Imran: Verse 159. The Almighty God's messenger said " Almighty God and his Messenger (PPUH) do not need them. Therefore, Almighty God made it in terms of a mercy for my Ummah, whoever seeks for consultation (Shuraa) will find the right path, transmitted by Al-Bihaqi in The Book of Faith, 6/76, No. 7543. In addition, he said: "It is transmitted by Hassan Al-Basri from his saying, which is a strange one".

The summary of the above is that the prophet (PPUH) was reproached in some Quranic Verses and the alerts and directions he has been addressed, were not because of a sin nor a guilt that suspecting his infallibility, rather, his abandonment of what is more important in the knowledge of Almighty God which are hidden matters from him, in which there is no revelation, which are not revealed to him except through revelation. It indicated that he left the best and the primacy, and leaving the primacy is not considered a sin.

\subsection{The fourth suspicion:}

the violation of the caliphs and the companions of the Prophet's Sunnah, and this is what is shown by the orientalist Joseph Schacht " and with the death of the Prophet, of course, the legislation that was based on the revelation or on the authenticity of prophecy is over". It was natural that the first caliphs would try to follow the Islamic Ummah on the Sunnah, guided by the opinion of the prophet's great companions. The principles they were guided by was what was included in the Holy Quran, and from the authentic Prophet's judgments, which were not mentioned in the Holy Quran. Rather, when they tried to simplify these limited principles, they ended up expanding their interpretation away from their original meanings. It may have been the reason for the emergence of new Hadiths. At the same time, the caliphs were not deprived of legislative diligence. Rather, changing the judgments of the Prophet. Perhaps it is historically true that Abu Bakr was following the example of the Prophet (PPUH) in this matter. While Caliph Omar was more inclined to modify and change. However, the link to customary law remained unchanged. Even after being exposed to many foreign influences as a result of the great Islamic conquests of Iraq, the Levant and Egypt." (Al-Calipha, 1997, p. 132).

The response to this suspicion is that:

In order to respond to this suspicion, it is necessary to clarify the types of acts of the Prophet (PPUH) and their judgments in Islamic Sharia, and to clarify the sections of his acts, so that it is clear to the extent that the orientalists and those who agreed to their Sunnah are not satisfied with his acts, and that their statement is as follows:

First: his human acts: what he does under human nature, is what he does under human nature, such as eating, drinking, sleeping, freedom to do things, and so on, which is not related to worship acts. This is in the general public of scholars in which it does not require following his example, and it is not about a command nor a prohibition (Bukhari, 1997, 1/156). Second: Acts are specific to the Prophet such as his marriage to more than four wives at and same time and his continual fasting. Scholars did not dispute this, that it is not permissible to follow his example in regard (Badshah, D.T., 3/120).

Third: what he did to indicate the whole or his compliance with the command in the Holy Quran, or in AlSunnah's sayings, such as his clarification in how to pray, fast and hajj after the revealing of the verses. This type has been stated by the most fundamentalists that it does not depart from being a duty or a delegate, which its judgment is of the clarified judgment. If the act is a clarification of a duty, then it is a duty. If the act is a clarification for a desirable act, then it is desirable (Al-Fatuhi, 2003, 2/178).

Fourth: What he did in the first place was not a clarification of totality or compliance, his own or his human acts. This is either to be known as the legitimacy of the evidence or the agreement of the predecessors on its judgement. For example, I'etikaf, is desirable (mostahab) by all scholars although it was only proven by the 
Prophet's act, others find it desirable (mostahab), and its legal status is unknown and the purpose of closeness to Almighty God has not been shown up. This is a matter of contention among scholars. Furthermore, it is beneficial for entire permissibility, and it is not considered obligatory nor permissible, but some of them consider it as permissible, or its legislative characteristic is unknown, but what came out of it for the purpose of closeness to Almighty God was also e a disagreement between jurists and fundamentalists such as performing a kind of worship without keeping it on. It is more likely that the scholars say that it is considered desirable for the Ummah (Al-Amdi, 1404 H., 1/227-228). In short, the Sunnah occurred in different kinds of worships, not all of which are mandatory for the Ummah.

Moreover, the acts of the Prophet (PBUH) are limited to the judiciary and fatwa as for the imamate. As for his diligence (ijtihad) in achieving the mandatory in the judiciary and fatwa, it is to inform what Allah has prescribed in accordance with the evidence. This should not be discussed with the Prophet. As for his diligence (ijtihad) in the imamate, such as wars and their arrangements and worldly matters in public policy to control the interests of the people and their affairs and to ward off the mischiefs from them (Zirkshi, 2000m, 4/507).

This is what the Prophet (PBUH) used to discuss and consult the Sahaba for, as Almighty God has addressed him with this by saying: [ عَشَاوِر هُم فِي ألأَمرِ] (and consult them in affairs (of moment) Surrah Aal-E-Imran: Verse 159. It is also stated that the Sahaba, May Almighty God be pleased with them, have asked the Prophet in one of their worldly issues, "The story of the accustoming of the palm trees". He said to them, "What are you doing?" and they replied, "We have been accustomed to do it." He said, "Perhaps if you did not do it would be better so they gave it up, but the crop was diminished. They mentioned that to him and he said, "I am only a human being. When I issue any command to you regarding your religion, accept it; but when I issue any command to you based on my own opinion, I am merely a human being". In another transmission in Sahih Muslim, (You have better knowledge (of a technical skill) in the affairs of the world.) The Book of Virtues, The Chapter to compliance with what he said ....(4/1835), No. 2362). Nawawi mentioned in his book the Explanation of Sahih Muslim " The scholars said his words. From my point of view " That is about the worldly issues not in the legislation, as for what he said with his diligence (ijtihad) that is related to the legislation must be followed" (Nawawi, 1392H, 15/116). It turns out that his diligence (ijtihad) may be a merely opinion that is unrelated to legislative judgements, such as his diligence (ijtihad) in wars or in the worldly matters. Thus, orientalists' claims, that his acts are purely human, have dropped. Even those with regard to the matters related to religion.

None of the caliphs or companions has proven to be opposed or violated any command or act of the Prophet. Because it is known to the Ummah that those who have proven their opposition to the Prophet (PBUH) are considered apostates of Islam. See: Abu Al-Hussein, 1403 Ah, 1/63) it cannot be imagined that this will happen from the companions of the Prophet. Rather, their effects reveal to us how careful they are to follow what the Prophet (PBUH) said, whether from his actual or sayings Sunnah. There are many examples about this but in here is not sufficient to mention them.

What the Orientalist Schacht said that, there is an expansion in the diligence (ijtihad) of some of the Sahaba as Omar. I say that the diligence (ijtihad) that occurred from the Sahaba or the Muslim scholars occurred in what they are authorized to do. Since the diligence (ijtihad) of the scholars is, where there is no Quranic text or consensus. Moreover, it is in the texts whether it is a belief in terms of significance or proof. The diligent (who performs ijtihad), in which the conditions of ijtihad have been completed, is doing his best to obtain the judgement for the incident. Using significant evidence, the Sharia has guided him to such as measurement (Qiyas), approbation (istihsan), AlSahabas' sayings, no to harm the interests, our ancestors' Sahria, common customs, Sadd Al-dhari'ah (hindering the causes of corruption), and the evidences from the Sharia are a lot, which cannot all be mentioned in this place. This is from the divine wisdoms, which urge the diligence and realization of thought because of the issues and events about which Muslim scholars cannot find clear Quranic texts. Therefore, there is no indication of AlSahaba s' violation of the Sunnah as stated by the enemies of Islam, or what indicates the failure of the Sunnah to solve the new upcoming issues. Rather, this is proof of the validity of Sharia for all times and places to demonstrate the resilience of all new issues and events that should be coming up with all times and places.

The content of this suspicion is that the Sahaba and the Caliphs do not abide by the Sunnah, but they may change the judgements of the Prophet. In addition to that contradicts with Schacht's statement when he said " Muslims considered the Sunnah to be impartial from the mistakes". He claimed that the Sahaba and the Caliphs do not hesitate to violate it. In addition, they are in fact the most severe people who follow his (PPUH) Sunnah. This is a clear contradiction in the words of orientalist Schacht, which shows the extent to which his claims are weak.

\section{Conclusion}

In this research, we have found out through the response and criticism of the suspicions of orientalists and some of those who agreed with them, (Arabs and Muslims) on the subject of the prophet's infallibility in his diligence (ijtihad) and acts, a number of issues, as follows: 
5.1 First: With a regard to the prophet's infallibility in his actions and diligence (ijtihad):

1. The Quran's indication to the prophet's infallibility in his acts and diligence (ijtihad).

2. The Muslims agreed on the prophet's infallibility in his acts and diligence (ijtihad), because the revelation is watching him and will not accept him when making mistakes.

3. The prophet's acts and diligence (ijtihad) are a part of Sharia that requires following up, except as evidenced by the prophet's characteristics.

5.2 Second: With a regard to orientalist studies:

1. In many orientalist studies, they rely on sources that are not at the level of scientific research.

2. Their aim is to slander and mislead, because if they sought the truth, they would return to the confirmed the books of the imams.

3. Incorrect translation for the texts resulting difficulty in understanding, and writing them in incorrect contextual texts.

4. Contradiction, in their claims and their statements to each other, appeared to us in more than one place, which indicates their decline and weakness.

In conclusion, this is what has been facilitated for us to research, which is the effort of the saying, we ask God to benefit us with what we have learned, and ask Almighty God to grant our Prophet Mohammad, his family members and companions prayers and peace.

\section{Acknowledgments}

This project was supported by the Deanship of Scientific Research at Prince Sattam bin Abdulaziz University, Saudi Arabia under the project No. 2020/02/16973.

\section{References}

Holy Quran

AlAmadi, Ali Bin Mohammed Abulhasan (1404H). Al-Ihkam Fi Osool Al-Ahkam (Investigated by Dr. Said Algamili) 1st Edition, Beirut: Dar Alkitab Alarabi

Badshah, Mohammed Ameen famed by Ameer (DT) Taiseer Altahreer, Beirut: Dar Alfikre

Al-Bukhari, Aladdin AbdulAziz bin Ahmed (1997). Kashf AlAsrar Ann Ossol Fakhr Al-Islam

Bazawi, the investigation of Abdullah Mahmoud Mohammed Omar, Beirut: Dar Alkotob Ali'lmyah

Al-Bihaqi, Abu Bakr Ahmad bin Al-Hussein (1410 Ah). Shoa'ab AlIman, investigated by Mohammed Al-Said Bassiouni Zaghloul, I1, Beirut: Dar Alkotob Ali'Imyah.

Al-Jazari, Abu al-Saadat Al-Mubarak bin Mohammad (1979). Alnihayah fi Ghareeb Alkawl wa Alathar, By Taher Ahmed Al-Zawi, Mahmoud Mohammed Al-Tanahi, Beirut: The Scientific Library

Al-Juwayni, Abu Al-Maali Abd Al-Malik bin Abdullah bin Yusuf (1996 AD) Book of Summary on Osool AlFiqqh, Investigated by Abdullah Jawlum Al-Nabali and Bashir Ahmad al-Omari, Beirut: Dar Al-Bashaer AlIslamiyya.

Al-Hussain, Mohammad bin Ali bin Al-Tayyib Al-Basri (1403 AH). Al-Mu'timad fi Osool Al-Fiqqh, Investigated by Khalil Al-Mays, 1st Edition, Beirut: Dar Al-Kutub Al-Ilmiyya.

Al-Khattabi, Abu Sulaiman Hamad bin Mohammad (1988 AD). Scholars of Hadith Explanation of Sahih AlBukhari, Investigated by: Dr. Muhammad bin Saad bin Abdul Rahman Al Saud, 1st Edition, Makkah AlMokarramah: Center for Scientific Research and the Revival of Islamic Heritage.

Al-Calipha, Mohammad Ibrahim Mohammad. (1997 AD), Orientalist Joseph Shakht's opinions about the authenticity of the Prophet's Sunnah through his book The Fundamentals of the Mohammadiyah Sharia, Unpublished MA Thesis, College of Da`awah, Imam Mohammad bin Saud Islamic University, Medina, Kingdom of Saudi Arabia.

Zarkshi, Badreddine Mohammed bin Bahadur bin Abdullah (2000). Albahr Almoheet fi Osool Alfiqqah, Investigated, the control of its texts and the transmission of the Hadiths and commenting on them: Dr. Mohammed Mohammed Tamer, 11th Edition, Beirut: Dar Alkotob Ali'lmyah.

Al-Shatibi, Ibrahim bin Musa bin Mohammad Al-Lakhmi Al-Gharnati (1997 AD). Almowafakat, Investigated by: Abu Ubaidah Mashhour bin Hassan Al Salman, 1st Edition, Kingdom of Saudi Arabia: Dar Ibn Affan.

El-Sherbiny, Emad El-Sayed (2003 AD). Responding to suspicions about the infallibility of the Prophet PPUH, in the light of the Qur'an and Sunnah, 1st Edition, Kingdom of Saudi Arabia: Dar Al Sahifah Press.

Al-Shahristani, Mohammad bin Abdul Karim bin Abi Bakr Ahmed (1404 AH), Al-Malal Wa Al-Nahl, investigated by: Mohammad Sayyid Kilani, Beirut: Dar Al-Marifa.

Abdul Qadir, Abdul Mahdi (2007 AD). Introduction to the Prophetic Sunnah, 1st Edition, Al-Mansoura: Aliman Library. 
Al-Asqalani, Ahmed bin Ali bin Hajar Abu Al-Fadl Al-Shafi'i (DT), Fath Al-Bari Sharh Sahih Bukhari, investigated by: Moheeb Al-Deen Al-Khatib, Beirut: Dar Al-Marifa.

Al-Attar, Hassan (1999). Al-Attar's Ga'am AlGawame'a, Beirut: Dar Alkotob Ali'lmyah.

Al-Fatohi, Mohammed bin Ahmed (2003) Explaining of Alkawkab Almoneer, investigated by:

Dr. Mohammed Al-Zuhaili, Dr. Nazih Hammad Makkah: Institute for Research and Revival of Islamic Heritage.

Al-Mardawi, Ala Al-Din Ali bin Suleiman Al-Hanbali (2000 AD). Al-Atheer Explanation of Al-Tahrir in Osool Al-Fiqqh, investigated by: Dr. Abdul Rahman Al-Jibreen. Dr. Awad Al-Qarni. and Ahmed Al-Sarrah, 1st floor, Riyadh: Al-Rashed Library.

Manthoor, Mohammad bin Makram Al-Afriqi (DT) Lisan Al Arab, 1st floor, Beirut: Dar Sader.

Al-Nawawi, Abu Zakaria Yahya bin Sharaf bin Meri (1392Ah). Sahih Muslim Explained by AlNawawi, 2nd Edition, Beirut: The House of the Revival of Arab Heritage.

Al-Yahsobi, Judge Abu fadl Iyad bin Musa (1984). Al-Shafa'a in identifying Al-Mustafa's Rights, investigated by Ali Mohammed Al-Bejawi, Beirut: Arab Book House. 